Artikel Penelitian

\title{
PROBLEMATIK KOMPETENSI GURU MATA PELAJARAN SEJARAH INDONESIA INDONESIA DI SMKN 1 JEMBER
}

\author{
Puji Rizki Irani, Wiwit Nur Habibah, Intan Gladys, Ivan Eldiansyah, Bambang Soepeno, \\ Rully Putri Nirmala Puji \\ pujirizkiirani25@gmail.com \\ Program Studi Pendidikan Sejarah Jurusan Pendidikan Ilmu Pengetahuan Sosial, \\ Fakultas Keguruan dan IImu Pendidikan, Universitas Jember (UNEJ)
}

Abstract: History teachers have their own problems related to their own competency. This is based on the historical materials acquistion for X grade until XII grade. In this research, the author uses mixed-method research which employs quantitative and qualitative data as the fundamental reference. This research has been done in SMKN 1 Jember and found three problems related to history teachers competency which include the lack of teaches in describing the scope of historical studies, the lack of using historical aids, and the lack of giving pleasure to students in learning history. This paper, the author also gives solve for the teacher to address those problems.

Key Words : Problematic competence, history teachers

\section{PENDAHULUAN}

Pembelajaran sejarah SMA baik kelompok peminatan maupun kelompok wajib dalam tiap tingkatan seharusnya mempunyai pendekatan berbeda, sehingga tidak membuat peserta didik cepat bosan dan lebih mudah menangkap maksud yang diterangkan oleh pendidik. Pendekatan ini tidak terlepas dari kompetensi yang dimiliki guru sejarah itu sendiri. Dimana dengan menguasai kompetensi sejarah dengan baik, seorang guru sejarah dapat mengimplementasikan atau mengaplikasikannya dalam proses kegiatan belajar mengajar di kelas (Hamid,2013:27).

Beranjak dari uraian singkat diatas membuat peneliti ingin mengetahui lebih lanjut tentang permasalahan-permasalahan yang muncul terkait kompetensi guru sejarah saat JPSI, Vol. 1, No. 2, 2018 
ini. Oleh sebab itu penelitian ini bemaksud untuk mengetahui problematik kompetensi guru mata pelajaran Sejarah Indonesia di SMKN 1 Jember. Dari kuesioner yang telah dibagikan kepada murid kelas X Broadcasting 2 menunjukkan adanya tiga pokok permasalahan atau problematik terkait indikator dalam kompetensi guru mata pelajaran Sejarah Indonesia. Permasalahan pertama, guru kurang dapat mendeskripsikan ruang lingkup kajian sejarah, kedua guru kurang menggunakan ilmu bantu sejarah, dan yang ketiga guru kurang memberikan kesenangan (rekreasi) dalam diri siswa dari adanya belajar sejarah.

Di samping melakukan observasi secara langsung dengan menyebarkan angket atau kuesioner kepada murid. Peneliti juga melakukan sesi wawancara dengan salah satu guru sejarah SMKN 1 Jember bernama Ibu Susi Susanti, S.Pd. Dari hasil wawancara tersebut tidak terdapat permasalahan yang terlalu signifikan terkait kompetensi guru mata pelajaran Sejarah Indonesia. Namun narasumber mengungkapkan ada beberapa siswa yang kurang berminat terhadap mata pelajaran Sejarah Indonesia. Sehingga permasalahan tersebut perlu adanya solusi terbaik agar membuat murid lebih aktif dalam kegiatan belajar mengajar.

Problematik kompetensi guru mata pelajaran Sejarah Indonesia ini tidak terlepas dari sosok guru sejarah itu sendiri dalam memahami materi sejarah dengan baik dan benar dari kelas X sampai dengan kelas XII. Maka sebagai seorang guru dengan latar belakang sarjana pendidikan sejarah seharusnya lebih menguasai bahkan mendalami semua materi sejarah yang diajakarkan dengan baik serta dapat mengimplementasikannya pada saat kegiatan belajar mengajar di kelas berlangsung. Berdasarkan keterangan di atas membuat peneliti tertarik untuk mengkaji lebih dalam mengenai problematik kompetensi guru sejarah, peneliti mengambil judul "Problematik Kompetensi Guru Mata pelajaran Sejarah Indonesia di SMKN 1 Jember" dalam penulisan artikel ini.

\section{METODOLOGI PENELITIAN}

\section{Jenis Penelitian}

Penelitian ini menggunakan jenis penelitian campuran atau mix method dengan data kuantitatif dan data kualitatif sebagai acuan. Data kuantitatif yang digunakan adalah 
hasil kuisioner yang telah dibagikan pada murid kelas X Broadcasting 2 dengan jumlah 30 siswa. Selanjutnya data kuantitatif tersebut akan disalin ke dalam IBM SPSS untuk mengetahui permasalahan yang paling signifikan dalam penelitian tersebut. Sedangkan data kualitatif didapat dari hasil wawancara langsung dengan salah satu guru Sejarah yaitu Ibu Susi Susanti, S.Pd.

\section{Sampel}

Penelitian dilaksanakan pada hari Senin, 05 November 2018. Fokus dari tempat penelitian ini berada di SMKN 1 Jember. Alasan pemilihan tempat penelitian di SMKN 1 Jember karena merupakan sekolah menengah kejuruan di Kabupaten Jember yang termasuk sekolah favorit. Sehingga peneliti ingin mengetahi sejauh mana problematik kompetensi guru sejarah di sekolah favorit. Subyek yang digunakan dalam penelitian ini adalah guru sejarah SMKN 1 Jember salah satunya adalah Ibu Susi Susanti, S.Pd. Sedangkan obyek penelitian yang ingin diketahui oleh peneliti adalah problematik kompetensi guru mata pelajaran Sejarah Indonesia. Penelitian ini dilakukan dengan mengambil sampel murid kelas X Broadcasting 2 dengan jumlah 30 siswa.

\section{Teknik Pengambilan Data}

Perlunya suatu metode yang tepat untuk memilih teknik pengumpulan data yang kredibel dan relevan, sehingga memungkinkan memperoleh data yang benar-benar objektif. Jadi Metode yang digunakan dalam penggumpulan data tersebut adalah:

\section{Wawancara (Interview)}

Wawancara merupakan percakapan yang melibatkan dua orang atau lebih yang mana peneliti mengajukan pertanyaan sedangkan objek penelitian sendiri menjawabnya (Damin, 2002: 130). Teknik wawancara yang digunakan dalam penelitian ini adalah wawancara mendalam, artinya wawancara di sini merupakan strategi utama dalam pengumpulan data. Narasumber dalam penelitian ini adalah salah satu guru Sejarah di SMKN 1 Jember. Peneliti menyiapkan rekaman audio untuk merekam hasil dari wawancara untuk menjaga kredibilitas. Peneliti menyiapkan garis besar pertanyaan yang digunakan dalam wawancara.

\section{Dokumentasi}

Teknik dokumentasi ini mengambil data yang diperoleh melalui beberapa dokmen (Usman dan Setiady Akbar, 2001:73). Pada metode ini, peneliti memperoleh informasi dari 
berbagai macam sumber tertulis dan dokumen mengenai data guru, siswa, RPP silabus dan keadaan umum di SMKN 1 Jember.

Angket atau Kuesioner

Penelitian ini menggunakan angket atau kuesioner yang mana angket tersebut berupa beberapa pertanyaan tertulis sebagai acuan untuk mendapat informasi dari responden (Sugiono,2010:199). Angket atau kuesioner yang dibagikan kepada siswa terdiri dari 16 pernyataan, dimana siswa diminta untuk mencentang pada kolom angka 1 - 5. Keterangan angka pada tiap kolom adalah sebagai berikut :

1 = Sangat Tidak Setuju

2 = Tidak Setuju

3 = Ragu-ragu

$4=$ Setuju

5 = Sangat Setuju

Tabel 1. Kisi-Kisi Angket Problematik Kompetensi Guru Mata pelajaran Sejarah Indonesia

\begin{tabular}{|c|c|c|c|c|}
\hline NO & $\begin{array}{l}\text { VARIABEL } \\
\text { PENELITIAN }\end{array}$ & INDIKATOR & $\begin{array}{l}\text { JUMLAH } \\
\text { BUTIR }\end{array}$ & $\begin{array}{l}\text { NOMOR } \\
\text { BUTIR }\end{array}$ \\
\hline \multirow[t]{4}{*}{1} & \multirow{4}{*}{$\begin{array}{l}\text { Problematik } \\
\text { kompetensi } \\
\text { guru mata } \\
\text { pelajaran } \\
\text { Sejarah } \\
\text { Indonesia }\end{array}$} & $\begin{array}{l}\text { Menguasasi hakikat } \\
\text { struktur keilmuan, ruang } \\
\text { lingkup, dan objek Sejarah }\end{array}$ & 4 & $1,2,3,4$ \\
\hline & & $\begin{array}{l}\text { Membedakan pendekatan- } \\
\text { pendekatan Sejarah }\end{array}$ & 4 & $5,6,7,8$ \\
\hline & & $\begin{array}{l}\text { Menguasai materi Sejarah } \\
\text { luas dan mendalam }\end{array}$ & 4 & $9,10,11,12$ \\
\hline & & $\begin{array}{l}\text { Menunjukkan manfaat } \\
\text { mata pelajaran Sejarah } \\
\text { Indonesia }\end{array}$ & 4 & $13,14,15,16$ \\
\hline
\end{tabular}




\section{Teknik Analisis Data}

Langkah-lanhkah analisi data yang dijabarkan oleh Creswell adalah sebagai berikut:

a. Mengolah data untuk dianalisis, yang mana melibatkan transkripsi wawancara, menscanning materi, mengetik data lapangan, atau memilah-milah dan menyusun data tersebut ke dalam jenis-jenis yang berbeda tergantung pada sumber informasi;

b. Membaca keseluruhan isi data, yakni dengan membangun general sense dari infomasi yang didapat dan kemudian ditelaah seluruh maknanya;

c. Menganalisis lebih detail dengan mengkoding data, coding dapat diartikan sebagai suatu proses dalam pengolahan informasi menjadi beberapa tulisan atau segmen sebelum dimaknai (Creswell, 2015:276).

Instrumen Penelitian

Langkah-langkah penelitian atau dalam buku Creswell (2015:2017) disebut aktivias-aktivitas yang dilakukan pengambilan atau pegumpulan data yaitu: 1) Menentukan tempat/individu; 2) Memperoleh akses dan membangun hubungan; 3) Sampling Purposeful; 4) Mengumpulkan data; 5) Merekam Informasi; 6) Memecahkan persolaan lapangan; 7) Mengumpulkan data. Terdapat langkah yang penting dalam peneltian tersebut, misalkan menemukan masyarakat atau tempat yang akan dipelajari, membangun hubungan dengan mereka sehingga dapat memberikan data yang bagus. Langkah tersebut berkaitan erat dengan strategi dalam sampling individu maupun tempat.

Alat Analisis Data

Alat analisis data yang digunakan adalah aplikasi IBM SPSS, dimana aplikasi tersebut dapat menguraikan data yang telah diperoleh di lapangan atau hasil kuesioner dalam bentuk deskripsi analisis. Sehingga peneliti dapat menemukan pokok permasalahan yang paling krusial dalam penelitian tersebut.

\section{HASIL DAN PEMBAHASAN}

Pada bagian ini akan diuraikan hasil interpretasi data yang sudah diteliti dari hasil kuesioner maupun wawancara di lapangan. Sebagaimana telah diuraikan pada bagian sebelumnya, bahwa penelitian ini difokuskan pada problematik kompetensi guru mata 
pelajaran Sejarah Indonesia di SMKN 1 Jember. (Tabel deskriptif statistik (IBM SPSS) terdapat pada lampiran) Namun dihalaman berikutnya akan dijelaskan nilai konvensi mean dari data deskriptif statis beserta hasil analisisnya sehingga dapat diketahui permasalahan yang ada:

Nilai tertingi - Nilai terendah $: 5=(4,433-3,567) \div 5=0,866: 5=0,173$

$3,567+0,173=3,740 \rightarrow$ Sangat Rendah

$3,740+0,173=3,913 \rightarrow$ Rendah

$3,193+0,173=4,086 \rightarrow$ Sedang

$4,086+0,173=4,259 \rightarrow$ Tinggi

$4,259+0,173=4,432 \rightarrow$ Sangat Tinggi

Tabel 2. Nilai Konvensi Mean

\begin{tabular}{lll}
\hline Jenis Soal & Nilai Mean & Keterangan \\
\hline Soal 1 & 4,333 & Tinggi \\
\hline Soal 2 & 3,966 & Rendah \\
\hline Soal 3 & 3,800 & Sangat Rendah \\
\hline Soal 4 & 4,100 & Sedang \\
\hline Soal 5 & 4,133 & Sedang \\
\hline Soal 6 & 3,566 & Sangat Rendah \\
\hline Soal 7 & 4,133 & Sedang \\
\hline Soal 8 & 4,206 & Sedang \\
\hline Soal 9 & 4,233 & Sedang \\
\hline Soal 10 & 4,033 & Rendah \\
\hline Soal 11 & 4,333 & Tinggi \\
\hline Soal 12 & 4,433 & Sangat Tinggi \\
\hline Soal 13 & 4,206 & Sedang \\
\hline Soal 14 & 4,166 & Sedang \\
\hline Soal 15 & 3,966 & Rendah \\
\hline Soal 16 & 3,833 & Sangat Rendah \\
\hline
\end{tabular}

JPSI, Vol. 1, No. 2, 2018 
Hasil analisis dari menghitung nilai konvensi mean pada halaman 10 menunjukkan bahwa terdapat tiga pernyataan yang menunjukkan keterangan sangat rendah. Sehingga penulis menyimpulkan terdapat tiga pokok problematik atau permasalahan terkait kompetensi guru mata pelajaran Sejarah Indonesia, yang mana ketiga pernyataan tersebut adalah sebagai berikut:

Soal 3 : Guru dapat mendeskripsikan ruang lingkup kajian sejarah

Soal 6: Guru menggunakan ilmu bantu sejarah (arkeologi,paleontology dII)

Soal 16 : Guru mampu memberikan kesenangan (rekreasi) dalam diri siswa dari adanya belajar sejarah

Setelah melakukan interpretasi, peneliti selanjutnya menguraikan tiga permasalahan yang ditemukan sebagai berikut:

\section{Problematik Kompetensi Guru Mata pelajaran Sejarah Indonesia}

Guru merupakan salah satu ujung tombak bagi keberhasilan pembelajaran di Sekolah karena memiliki kedudukan yang sangat starategis. Sehingga tugas seorang guru sangat mempengaruhi mutu pendidikan di sekolah. Begitu juga dengan seorang guru sejarah hendaknya menguasai materi yang diajarkan agar murid dapat menangkap dengan baik. Materi ini disesuaikan dengan indikator kompetensi guru sejarah SMA/MA dan SMK/MAK (Peraturan Menteri Pendidikan Nasional Republik Indonesia Nomor 16 Tahun 2007).

Penelitian ini dilaksanakan di SMKN 1 Jember dengan menggunakan guru sebagai subyek peneliti, kompetensi guru sebagai obyek peneliti dan murid kelas X Broadcasting 2 sebagai sampel peneliti. Berdasarkan angket atau kuesioner yang telah disebarkan, didapat hasil bahwa terdapat 3 pokok problematik atau permasalahan kompetensi guru mata pelajaran Sejarah Indonesia. Ketiga pokok permasalahan tersebut diuraikan sebagai berikut:

\section{Guru kurang dapat mendeskripsikan ruang lingkup kajian sejarah}

Problematik ini termasuk ke dalam indikator "Menguasasi hakikat struktur keilmuan, ruang lingkup, dan objek Sejarah". Dalam penerapannya berarti guru kurang mendeskripsikan secara rinci kajian ruang lingkup sejarah. Sehingga otomatis siswa kurang dapat membedakan macam-macam ruang lingkup sejarah yang ada. Berikut beberapa ruang lingkup sejarah seperti dalam buku R. Moh. Ali (2005:21): 
a. Sejarah Sebagai Peristiwa, yaitu mengenai peristiwa yang telah terjadi dan peristiwa itu benar-benar ada. Dimana peristiwa tersebut bersangkutan dengan kejadian yang penting, nyata, dan aktual.

b. Sejarah Sebagai Kisah, yaitu mengenai penulisan peristiwa oleh seseorang yang idenya diambil dari sejarah. sejarah merupakan sebuah cerita yang mana didapat dari hasil interpretasi para serajawan terhadap jejak tinggalan sejarah sehingga ditemukan suatu fakta yang selanjutnya dapat menyusun sebuah cerita.

c. Sejarah Sebagai IImu, yaitu membahas mengenai kebenaran dari sejarah itu secara objektif. Sejarah sebagai ilmu lebih kepada pengetahuan dengan melakukan suatu penelitian dari suatu peristiwa sejarah.

d. Sejarah Sebagai Seni, yaitu mengenai sejarah yang ditulis dan diceritakan kembali sesuai faktanya namun bersifat seni. Walaupun pada dasarnya sejarah disusun dari data-data ilmiah, akan tetapi penyajiannya dala bentuk keindahan atau seni dari penulisnya.

\section{Guru kurang menggunakan ilmu bantu sejarah}

Problematik ini termasuk ke dalam indikator "Membedakan pendekatanpendekatan Sejarah" yang berarti berarti guru kurang menggunakan berbagai macam ilmu bantu sejarah seperti sebagai berikut (Madjid \& Wahyudi,2014:112-117):

a. Peleoantropologi : cabang ilmu yang mempelajari tentang manusia purba

b. Arkeologi : cabang ilmu yang mempelajari kebudayaan (manusia) masa lalu

c. Paleografi : cabang ilmu yang meneliti perkembangan bentk tulisan kuno

d. Epigrafi : cabang ilmu yang meneliti benda-benda tertulisa dari masa lalu

e. Ikonografi : cabang ilmu sejarah yang mefokuskan kepada mempelajari tentang identifikasi, deskripsi, dan interpretasi isi gambar

f. Numismatik : cabang ilmu yang mempelajari sejarah mata uang itu sendiri, cara pembuatannya, dan sejarah politik terbentuknya mata uang tersebut

g. Keraminnologi : cabang ilmu yang mempelajari tentang penelaahan peninggalan kuno terutama keramik-keramik hasil kebudayaan masayarakat lalu.

Guru kurang memberikan kesenangan (rekreasi) dalam diri siswa dari adanya belajar sejarah

Problematik ini termasuk ke dalam indikator "Menunjukkan manfaat mata pelajaran Sejarah Indonesia". Hal ini berarti guru dalam pelaksanaan kegiatan belajar 
mengajar kurang memberikan hiburan atau kesenangan (rekreasi) kepada peserta didik. Guru hanya terfokus pada materi yang disampaikan tanpa melihat kejenuhan dari peserta didik. Hal ini yang membuat siswa cepat merasa bosan dan kurang fokus terhadap materi yang disampaikan oleh pendidik.

Sedangkan hasil wawancara pada salah satu guru sejarah di SMKN 1 Jember yaitu Ibu Susi Susanti, S.Pd. menunjukkan bahwasanya tidak terdapat permasalahan yang terlalu berarti atau signifikan terkait kompetensi guru mata pelajaran Sejarah Indonesia. Narasumber hanya mengungkapkan permasalahan diluar konteks kompetensi guru sejarah. Permasalahan tersebut berkaitan erat dengan kurangnya minat sebagian siswa terhadap mata pelajaran Sejarah Indonesia itu sendiri. Sehingga dari permasalahanpermasalahan yang timbul tersebut perlu adanya solusi yang bijak agar murid dapat lebih aktif lagi dalam kegiatan belajar mengajar.

\section{Solusi Dari Problematik Kompetensi Guru Mata pelajaran Sejarah Indonesia}

\section{Solusi untuk kasus yang pertama}

Pemerintah menetapkan pelajaran sejarah Indonesia disampaikan pada jenjang Sekolah Menengah Kejuruan (SMK) dalam Kurikulum 2013, dengan bentuk pengajaran yang tentunya sangat berbeda dengan pengajaran sejarah sebelumnya. Perbedaan tersebut terlihat dari pendekatan yang dipergunakan dalam menyampaikan materi kepada peserta didik. Sebelum Kurikulum 2013, berkembang pandangan dominan terhadap pelajaran sejarah sebagai pelajaran hafalan yang membosankan karena banyak hal yang harus dihafalkan. Hal ini disebabkan dalam pembelajaran sejarah yang dikejar adalah materinya itu sendiri (Aman, 2011:45).

Pembelajaran sejarah menurut Kurikulum 2013 berusaha untuk memandang sebuah peristiwa sejarah secara utuh, sehingga pembelajaran sejarah bukan sekedar kapan dan di mana, tapi mengapa. Dengan demikian, guru harus bisa membawa peserta didik berpikir kritis dan masuk kepada zamannya. Oleh karena itu pembelajaran sejarah diharapkan mampu mengembangkan pengetahuan, yang meliputi penerapan konsep, prinsip, atau menganalisis masalah, dan mengevaluasinya, mengembangkan keterampilan, mengolah informasi, menerapkan prosedur hingga mengamalkan nilai-nilai kesejarahan. Semua proses di atas perlu dilatihkan secara terus menerus kepada peserta didik lewat proses pembelajaran. 


\section{Solusi untuk kasus yang kedua}

Sumber sejarah merupakan segala jejak yang ditinggalkan dan tentunya memilik nilai informasi berharga terkait dengan objek yang direkontruksi. Karena sejarawan dihdapkan dengan ragam jejak masa lalu, maka sulit baginya untuk mengkaji sumbersumber itu bila hanya mengandalkan ilmu sejarahnya. Keterbatasan sejarawan menjangkau semua sumber-sumber itu membuatnya harus mencari alternatif lain yang dapat memudahkan pekerjaan rekonstruksinya. Oleh karena itu, pada tahap inilah sejarah butuh ilmu lain sebagai ilmu bantu (Hamid, 2011:25-26).

Cakupan dari sejarah terlalu luas, maka dari itu sejarah memerlukan ilmu bantu, penggunaan ilmu-ilmu bantu ini tergantung pada pokok-pokok atau periode sejarah yang akan dipelajari. Dalam pembelajaran guru harus bisa mengaitkan sejarah dengan ilmuilmu bantu, sepertinya halnya sosiologi, antropologi, politikologi, paleografi, dll. Karena cakupan dari sejarah sendiri itu sangat luas. Meskipun pembelajaran di SMK mata pelajaran yang dihadapi tidak sama dengan mata pelajaran SMA, guru harus bisa menjelaskan dan mengaitkan sejarah dengan ilmu-ilmu bantu sejarah.

\section{Solusi untuk kasus yang ketiga}

Memberi kesenangan (rekreasi) terhadap siswa dengan adanya belajar sejarah bisa juga dilakukan dengan mengunjuni situs-situs terdekat. Akan tetapi, selain itu juga dapat dilakukan dengan merubah metode pembelajaran. Tentunya tidak monoton sehingga siswa dapat merasakan kesenangan dalam pembelajaran. Metode pembelajaran yang dimaksud ialah metode role playing. Menurut Miftahul A'la dalam bukunya Quantum Teaching (2011:49) metode pembelajaran role playing (bermain peran) adalah merupakan cara penguasaan bahan-bahan pelajaran melalui pengembangan imajinasi dan penghayatan yang dimiliki oleh setiap siswa.

Pengembangan imajinasi dan penghayatan dilakukan siswa dengan memerankan memerankan sebagai tokoh hidup atau benda mati. Permainan ini umumnya dilakukan lebih dari satu orang, itu bergantung kepada apa yang di perankan. Selain dapat mengembangkan imajinasi yang dimiliki siswa, metode ini juga dapat membangkitkan kesenangan dalam diri siswa untuk dapat memerankan peran yang diinginkan.

\section{KESIMPULAN}


Dalam penelitian ini terdapat tiga permasalahan pokok yang ditemukan dan berkaitan dengan problematik guru mata pelajaran Sejarah Indonesia. Hal ini mengindikasikan bahwa seorang guru sejarah kurang memilki kompetensi yang memadahi terkait materi pembelajaran sejarah. Hal ini bisa terjadi dari kurangnya minat guru untuk turut aktif dalam proses belajar mengajar. Karena pada dasarnya tidak semua guru memiliki kemampuan dalam menghidupkan kelas. Disamping faktor pendidik, dari hasil wawancara yang telah dilakukan pada salah satu guru di SMKN 1 Jember dapat ditemukan bahwa faktor peserta didik (siswa) juga turut serta dalam tidak berjalan proses belajar mengajar yang semestinya.

Dari uraian diatas, peneliti memberikan tiga solusi terkait permasalahan yang ditemukan dilapangan. Namun solusi yang diberikan semata-mata hanya menanggulangi dampak yang jauh lebih besar jika seorang peserta didik tidak bisa menerapkan solusi tersebut atau dapat dikatakan mengabaikan kondisi belajar mengajar yang semakin buruk. Hal ini juga tergantung sejauh mana pendidik (guru) tersebut memaknai setiap pemasalahan yang ada dan dapat mengimplementasikan atau mengaplikasikan solusi dengan sebaik mungkin.

\section{DAFAR PUSTAKA}

Ali, R. M. 2005. Pengantar Ilmu Sejarah Indonesia. Yogyakarta: LkiS.

Creswell, J. W. 2013. Qualitative Inquiry \& Research Design. Choosing Among Five Appoaches. Terjemahan oleh A. L. Lazuardi. 2015. Penelitian Kualitatif \& Desain Riset: Memilih di antara Lima Pendekatan. Yogyakarta: Pustaka Belajar.

Damin, S. 2002. Menjadi Peneliti Kualitatif. Jakarta: CV Pustaka Setia.

Hamid, H.S. 2013. Problematik Pendidikan Sejarah. Yogyakarta: UPI-Press.

Madjid, M. D., \& J. Wahyudi. 2014. Ilmu Sejarah: Sebuah Pengantar. Jakarta: Prenada Media Group.

Peraturan Menteri Pendidikan Nasional Republik Indonesia Nomor 16 Tahun 2007. Standar Kualifikasi Akademik dan Kompetensi Guru. Jakarta. Akademik.dan Kompetensi Guru. 4 Mei 2007. Jakarta.

Peraturan Pemerintah Republik Indonesia Nomor 74 Tahun 2008. Guru. Jakarta.

Sanjaya,W. 2007. Strategi Pembelajaran Berorientasi Proses Pendidikan. Jakarta: Kencana.

JPSI, Vol. 1, No. 2, 2018 
Sugiono. 2010. Metote Penelitian Pendidikan-Pendekatan Kuantitatif, Kualitatai dan R\&B. Bandung: Alfabata.

Tokan, P.R.I. 2016. Manajemen Penelitian Guru untuk Pendidikan Bermutu. Jakarta: PT. Grasindo.

Undang-Undang Republik Indonesia Nomor 14 Tahun 2005. Guru dan Dosen. Jakarta: Lembaran Negara Republik Indonesia Tahun 2005.

Usman, H., \& S. Akbar. 2001. Metodelogi Penelitian Sosial. Jakarta: Bumi Aksara. 